\title{
Strategies to withstand the environmental damage through local wisdom
}

\author{
Marcellina B. Capellita ${ }^{1}$ Adinda Bunga Utami ${ }^{2}$ Nanny Sri Lestari ${ }^{3}$ \\ \{1brillian.capella@gmail.com, ${ }^{2}$ adindab8@gmail.com, ${ }^{3}$ nanny-s1@ui.ac.id\} \\ ${ }^{123}$ Universitas Indonesia
}

\begin{abstract}
Environmental damage has occurred all over the world. It often happens that the moral aspect, which is related to human behavior, becomes the main problem, which is hidden behind a story. But of course how to express the problem of environmental damage is certainly not done explicitly, but many are done implicitly. For example, people no longer see the river as an important natural element in human life, but the river is often seen as a place to dispose of garbage. The purpose of this research is to understand the damage to the natural environment and explore efforts to prevent environmental damage, which is done by the community. In particular, to prevent the environmental damage, by understanding the natural of human behavior, through local wisdom. This study uses a qualitative research paradigm procedure. The results showed that the qualitative research paradigm because qualitative procedures provide an opportunity for researchers to be able to interpret the data. The results showed that, there is one simple view of the community, who care about environmental balance. For the community the natural environment is the main breath of life when humans must live on earth. That is why the natural environment is a very important place in supporting the needs of human life, especially water. The easiest place to get water is the river. Therefore the existence of a river is very important. Rivers and animals that live around rivers are a buffer for human life.
\end{abstract}

Keywords: story, animal, moral, environment, message.

\section{Introduction}

In the perspective of some experts, the natural place of human habitation is the main supporting environment of human life. Environmental damage has occurred all over the world.. Those damage are happened in basic needs or basic human needs. These basic needs are indeed available on earth but their availability must be maintained. Fresh water is available through lakes and rivers. Lots of rivers, that function as a means to meet human needs for the needs of daily life. Lake is also considered as a source of water that can be needed for the needs of human life [1]. This research tries to explore the strategies to prevent damage to the natural environment through inheritance of local wisdom. The main needs of humans for water, especially fresh water in general are obtained from certain places. Fresh water is usually obtained from lakes, in the mountains, rivers that flow on land or water that comes out of the cracks of rocks around which there are springs. But in general humans are very much 
getting water from rivers. The water obtained from the river flow is very important for human life. This river water is used to sustain all human life. Starting from the needs of household life, to the need to irrigate fields and gardens. Some important research about stories related to rivers and aquatic animals, there have been several that have been carried out by research experts. Some reseach shows that the story of frogs and ants that live on the banks of the river, is a symbolism of the existence of elements of life that need the river as a buffer of daily life. Through this story it is seen that the community wants that the environment such as rivers and the animals and plants around them must be maintained by humans to prevent environmental damage. Other researchers found that the ecosystem that occurs along the river bank is an arrangement of life characteristics that is supported by the presence of water. On the other side the idea of aquatic animals that live in nature can provide inspiration to create a story. This is found in folklore. There was a strong enough effort from the community to maintain the balance of nature [2]. The effort is not done physically but more is done in a simpler way. People only convey messages from generation to generation through a story, accompanied by concrete actions in protecting the environment.

This research is an effort to explain the views of the people that have happened for generations in giving meaning and conveying messages on the role and function of rivers and aquatic animals, in maintaining the balance of nature. The way the community works in conveying this feels very simple, but behind all these activities, there is a message and a very deep meaning. There is a saying in the community that water flows in rivers to follow the curves of the earth's crust. This means that there is already a way for running water. This view implies that humans have long known the ins and outs of the river flow. The community at large realizes that the river is a buffer for their daily needs. The activity of maintaining the ecosystem around the river is shown through the many traditional rituals related to the river and river water. This ritual shows that the community does have a certain perspective in applying their thoughts and knowledge about rivers [3].

This research is an interdisciplinary study of literature and culture. This research is a research that starts from a deep curiosity about the role and function of the river for the community. The community's point of view on the role and function of the river is not a coincidence, but rather a long series of people's thoughts on the natural environment in which they live. Submission of a view of something that is very decisive in everyday life is based on a deep reflection on the synergy of human life with nature. Humans and the natural environment are a unity of life. The previous three studies describe the conditions of animal life in the actual natural environment. The community utilizes the natural environment according to their community's understanding. It often happens that people take advantage of the existing natural environment, without realizing the damage to the natural balance that occurs. The focus of this research is aimed more at community efforts to improve environmental conditions through moral education. This effort is carried out by compiling a story that is expected to make the public aware of the importance of the balance of natural environmental conditions [4]. The community realizes that the natural environment is the main buffer of human life. God created the natural environment on earth so that humans could live on earth. All the needs of human life for life on earth are provided in the natural environment. Humans must process everything available in nature to meet their needs. The needs of human life, in this world must be regulated. There are certain limits that must be obeyed. By adhering to the limits of natural living needs, it is expected that humans will not damage what is already available in nature. 


\section{Research Method}

This research was conducted by observing the environmental damage that occurred in the environment where humans live. From a number of observations on community activities there is one activity that is quite interesting, namely efforts to prevent environmental damage by instilling awareness in the community through storytelling or storytelling. These tales are certainly associated with the surrounding natural environment, for example fairy tales or children's stories related to animals or aquatic animals. There are several fables related to water, among others, turtles (turtle), keyong, fish, snakes, worms and others. In this study what will be observed as a basis is folklore about white turtle or white turtle. As a folklore, the story of the Bulus putih (white turtle) is part of literary work. Literary work itself is the result of community culture. For this reason, one method must be chosen to explain the phenomenon contained in the story [5].

This research can be categorized as a qualitative research paradigm procedure because it depends more on the interpretations of researchers. The initial tracing of the object of research is to explore the various possibilities of collecting the required data. The data is divided into two groups, namely data groups categorized into inductive data (or from the story itself) and data categorized into deductive data groups or ways of thinking or perspectives of the people supporting the story. Thus, this research was carried out on the basis of a textual approach to a folklore which in this case was written in the form of a story script.

\section{Results And Discussion}

\subsection{Story structure and story patterns}

Society in Indonesia in general, and Javanese people in particular, are familiar with stories related to their lives. If traced since time immemorial, a story is usually arranged based on community knowledge of the environment. Such knowledge is certainly compiled on the basis of people's life experiences in their daily lives. The life experience of the people in each region must be different. Life experience is based on the ability of people to manage and control their environment. The main focus in storytelling is community efforts to utilize storytelling activities, as an effort to prevent environmental damage [6]. You do this by making a story that tells about life in the river environment or how people in a good way can use the river and its contents to meet all of their daily lives. The river becomes the main foundation in meeting the needs of the community. Therefore the river becomes a very important thing in human life. To convey the importance of rivers for human life from time to time, stories are made that can be conveyed from generation to generation.In daily life there can be seen various types of animals in the natural environment. Aquatic animals are one of the most important parts of life. In everyday conditions, a lot of aquatic animals that have a very high economic value. Not only that, aquatic animals also have environmental values and cultural values. As an economic value, many people use it to refute their daily needs [7]. For example, for this type of machination, many take their skin to make household appliances. While turtle eggs are often traded for human food needs. It is this situation that encourages people who are well aware of the function of the natural environment, trying to save these turtle or turtle animals. This study, which further raised the sacred value of this turtle, shows that the public intentionally attaches this sacred value to these tortoise animals. Besides this sacred value 
intends to lift that this animal is very important for environmental balance. It also shows that the main value of the most important thing in life is to maintain the balance of the natural environment [8]. The trick is not to damage one element of nature, and one element of nature that is very trusted to be able to maintain the balance of nature is a turtle animal.

Like most other stories or fairy tales, the story of a white fleeced has a story structure that consists of a story line that contains a series of events, characters and settings related to the river. The series of events that occur in the story line carries a load of meaning and message that must be captured by the reader / listener of the story. In everyday life this story is often considered boring because almost all stories told always have a certain pattern. The pattern of the story is always associated with a close relationship between humans and their natural environment. This Bulus Putih folklore is interesting to study because Bulus Putih animals can live in two environments namely water and land.

\subsection{Case story of Bulus Putih (siebenrockiella crassicollis)}

The story of Bulus putih is a children's story in Java. The story is about the life of the people who live by the river. Children who live on the banks of the river generally know two environments, namely the land where they live and the river as a place to support their daily needs. White fairy tale or story is a very simple story for children. However, after careful attention this story is not as simple as people think.

Turtles (testudinidae) are animals that can live on land or in water. This animal has many kinds. In general, turtles that live in tropical areas such as islands in the archipelago such as Java are siebenrockiella crassicollis or white flat turtles. While the people call it white turtle. This species was first discovered by Gray 1830. This animal is spread on the islands of Java, Sumatra and Kalimantan. This turtle or turtle is traditionally an animal that is familiar with humans. In Hindu mythology, the story is known that the earth was shouldered or supported by four turtles. The same thing is also found in Adiparwa's story that the turtles have a very important role because they support the mountain to be turned to stir the ocean in an effort to search for living water [9].

In this study, the folklore studied was a white turtle (a white turtle) that tried to save a young woman from the pursuit of a giant who wanted to kill her. Logically this story is very simple, but there is a purpose behind this story. This story has a very loose story setting, meaning both the time and place are not explicit, mentioning a name. The composer of the story can just give the background name of the story in accordance with the desired background story. Besides the time is not determined strictly, simply referred to by the term in ancient times, which means very relative without a certain count. As worthy of other folklore, the story of this white machination also begins with the adjustment, recognition of various things, such as the introduction of characters, portrayal of the natural state, environment, atmosphere of the place, the relationship of time, etc. that can guide the reader emotionally to the situation of the story. This Bulus Putih story does have many versions which depend on the location of the people who are familiar with this story.

3.3 Efforts to Prevent Damage to the Natural Environment

If examined closely then a story is a communication that occurs in the midst of the community supporting the story. Even not, just ordinary communication but communication from generation to generation. Even in some areas that have variants of the story of white machination, this story even becomes a myth that is very attached to the community. There is a study that found that a story is arranged in accordance with the ability of the community to communicate. Therefore, in a story has a meaning and message that is often different even though in the same variant of the story. Furthermore, the communication element shows the 
role and function of the story as a cultural communication tool. The role here means the ability of a story to be used as a means of building or a means of understanding the viewpoints of the people who are supporters or owners of the story [10]. In daily life there can be seen various types of animals in the natural environment. One is a water animal. Aquatic animals are one of the many animals that have a function for the balance of nature. This turtle type aquatic animal has economic value, environmental value, cultural environmental value. As an animal that has a cultural environmental value, things related to turtles have been widely discussed. Especially with regard to economic value, too much has been discussed. There is one interesting thing about this cultural environment that people rarely pay attention to is the human effort to save the natural environment, especially related to this animal. This human effort by creating folklore is reinforced with elements of myth in animals and the location of their existence. In this way it is hoped that the sacred value affixed to the animal can lift and at the same time keep the community willing to care about the animal and its natural environment. The balance of the natural environment is needed to support human life on earth. Turtles are considered as animals that can support human life as long as humans do not damage the natural environment in which the tortoise and its environment are located [11].

In terms of cultural communication, what must be explored carefully is the meaning and message of the story. In terms of the meaning of the story of white machination with this variant, there is a meaning in terms of white machination as a character that plays a role in the story. Bulus Putih (white turtle) is an animal that has a gentle way of walking. The way the Bulus putih (turtle) is personified as a character that is very careful, and not in a hurry. This is a personification of parents who are rich in experience, who have experienced ups and downs in life [12]. This kind of character is considered by society as a character that has a role as $a$ protector for people who are weak or smaller. Also functions as a savior for people who are weaker or younger. In this story there is also an implied meaning, namely that someone who is experienced must be someone who already has enough age, meaning that person is an old person. For Javanese people, parents are an example or role model for younger people. Parents must be able to set a good example for the younger generation. Therefore this story has two sides, each parent must be an example and every young person must be willing to imitate good deeds. For the Javanese community the family is the safest place and source of protection from parents to their children. Parents are the first source of physical and spiritual well-being for children, and it is from parents that children receive all kinds of goodness [13].

The function of folklore is the main bridge for the community to pass on a very valuable message. In the white machination story, there are three things to convey the message, namely the message about family, community and the environment. The first message is that parents will not act quickly without calculation or in Javanese known as grusa-grusu. This expression is the opposite of the alon-alon waton kelakon, which means although slowly but successfully implemented. Acting slowly is to prevent an act leading to attitudes that damage the environment around the community. The second message is someone who is old, considered a person who already has extraordinary experience, so it must be able to be an example, protector and source of advice for the younger generation. Therefore, a parent is a person who is considered appropriate as paran takon (a place to ask) for young people or in Javanese parents are considered as paran takon for young people. At the same time parents become individuals who can provide efforts to prevent environmental damage. The third message, family life cannot be separated from the ups and downs experienced by young people. Same with the cause of damage to the natural environment. It is better to prevent natural damage than to improve the natural environment. 


\section{Conclusion}

The Bulus Putih story is not just a simple folklore. There are many things to be conveyed through this story. This story invites people to be wise in facing life. Human life does not only depend on work activities, but the environment must also be considered. Bulus Putih or siebencrockiella crassicolis is part of human life on earth. The natural environment gives humans everything that is needed. Not only the need to eat, as the main ingredient for continuing life but also clothing and shelter.

In addition to the above three things humans also have moral needs. The needs to set an example for a good life. These examples can be personified through other life in the natural environment. For example like white fleeced which is the personification of someone who already has enough life experience, so that he has a lot of wisdom and wisdom in his life. A person can also be called a parent. Parents are role models, protectors and saviors for young people who need help both in the community and family.

\section{References}

[1] L. Dsikowitzky et al., "Java Island, Indonesia," in World Seas: an Environmental Evaluation, 2019.

[2] T. Suliyati and D. R. Puguh, "A study on marine folklore of karimunjawa community for strengthening the social integration," Adv. Sci. Lett., 2017.

[3] S. Hartini, "Javanese Ethnic Local Wisdom in Farmer Community Folklore in South Coastal Area of Kebumen, Central Java By MV Sri Hartini HS," J. Ilm. Bhs. DAN SASTRA, 2017.

[4] I. R. A. P. Jati, "Local wisdom behind tumpeng as an icon of indonesian traditional cuisine," Nutr. Food Sci., 2014

[5] J. W. Creswell and V. L. Plano-Clark, "Choosing a mixed methods design," Des. Conduct. Mix. Method Res., 2011.

[6] S. M. Kushendrawati, "Wayang dan Nilai-nilai Etis: Sebuah Gambaran Sikap Hidup Orang Jawa," Paradig. J. Kaji. Budaya, 2016.

[7] N. Worth, "Feeling precarious: Millennial women and work," Environ. Plan. D Soc. Sp., 2016.

[8] A. B. Utami and N. S. Lestari, "FUNCTION, MEANING, AND MESSAGE OF THE NATURAL ENVIRONTMENT IN THE STORY OF KEONG MAS," Int. Rev. Humanit. Stud., 2019.

[9] H. Lorimer, "Telling small stories: Spaces of knowledge and the practice of geography," Trans. Inst. Br. Geogr., 2003.

[10] L. Aitken, "Turtle Island: The Story of North America's First People by E. Yellowhorn and K. Lowinger," Deakin Rev. Child. Lit., 2018.

[11] M. Idrus, "Makna Agama dan Budaya bagi Orang Jawa," Unisia, 2007.

[12] R. Lorand, "Telling a story or telling a world?," Br. J. Aesthet., 2001.

[13] G. Hansen, "Intangible cultural heritage and the better angels of folklore's nature," Int. J. Herit. Stud., 2016. 